\title{
Chapter 8 \\ Curriculum and Educational Reforms in Portugal: An Analysis on Why and How Students' Knowledge and Skills Improved
}

\author{
Nuno Crato
}

\begin{abstract}
By the turn of the century, following the dismal first results in TIMSS and PISA, the Portuguese educational system was at a crossroads. It was clear that students were not attaining minimal levels of proficiency in reading, math, science, and other basic subjects. The system needed a deep reshaping, and so changes were made. By the time the last PISA and TIMSS international large-scale surveys' results were released in 2015, Portugal registered a quantum leap: in PISA, student achievement was above the OECD average and in TIMSS, 4th graders had higher scores in Mathematics than several usually high-performing countries, including Finland. How was this possible? To understand what happened, we need to look at what Portugal has done in the last 10-15 years. Although many different ministers from different ideological standpoints made different reforms, there is a common thread to most changes: they paid increased attention to results. This proved to be a powerful thrust for improvement, backed up by experienced teachers. However, this general thrust assumed many concrete different aspects and promoted different reforms. During the 2011-2015 period, these reforms went further and were very clear, intentional, and explicit: a clear curriculum, increased school autonomy, students' regular assessment, vocational paths, flexibility. All this helped to prepare youngsters for an active, productive, and responsible life in the twenty-first century.
\end{abstract}

\subsection{Introduction}

Portugal arrived late at the twentieth century and took a long time to recover from illiteracy, poverty, isolation, and a very limited school system.

Only in 1956 was compulsory schooling extended from 3 to 4 years, and only for boys. The same extension included girls in 1960. In 1964, compulsory schooling was extended to 6 years and in 1967 the so-called preparatory unified cycle ("ciclo

\footnotetext{
N. Crato $(\bowtie)$

Cemapre, REM, ISEG, University of Lisbon, Lisbon, Portugal

e-mail: ncrato@iseg.ulisboa.pt
} 
unificado") was created, allowing all students to attain the same type of instruction until 6th grade. Only in 1986, compulsory schooling went up to the 9th grade. And only in 2012 up to the 12 th grade.

In the 1970 census, 4 years before the democratic revolution, almost $18 \%$ of the population was still illiterate, $66 \%$ of 15 -year old hadn't completed any level of formal education, and only $0.9 \%$ of the total population had a higher education degree. ${ }^{1}$

The progresses made during the last decades of the twentieth century are extraordinary. Following the general improvement of economic conditions after the 1960s, the euphory of a baby boom, a restored democracy, the entrance in the European Community, and the arrival of European structural funds, schooling expanded, and the country changed completely. In 30 years, as the 2001 census reveals, illiteracy dropped from $18 \%$ to $9 \%$, the percentage of 15 -year old without any level of formal education dropped from $66 \%$ to $9.2 \%$, and the fraction of the population with higher education raised from $0.9 \%$ to $8.4 \%$.

All these successes were essentially quantitative, i.e., they democratized education, expanded the school system, and increased compulsory schooling. But they apparently failed to bring youngsters to reasonable levels of literacy and general education. ${ }^{2}$ A debate about the quality of education divided the country.

On the one side, educationalists, promoters of reforms, politicians in power, and professors of the new teachers' colleges created in the late 80s replacing the old normal schools of education, all defended the system and sustained that democratization of education was not degrading the average level of middle and high school graduates.

On the other side, college professors, middle-age intellectuals, both from the traditional left and conservatives, accused politicians in power of degrading education, lowering standards, and bringing romantic and unrealistic ideas into the educational realm.

Although to take sides is highly contentious, one has to say that the first group rightly stressed the successes of democratization and correctly criticized a very traditional teaching system. By the same token, the second group rightly stressed the need to raise curricular goals and correctly criticized the flaky ideas that condemned basic knowledge as an outdated concept (Crato 2006).

Shocking news were awaiting the country. TIMSS 31995 showed Math 4th grade Portuguese students at the bottom of the scale, with only two countries, Iran and

\footnotetext{
${ }^{1}$ Pordata, https://www.pordata.pt/ consulted 3 August 2019.

${ }^{2}$ Similar analyses have been made in various contexts, highlighting the need to look for outcomes beyond the inputs. See, for instance, Donnelly et al. (2019).

${ }^{3}$ TIMSS (Trends in International Mathematics and Science Study) is a large-scale assessment designed to inform educational policy and practice by providing an international perspective on teaching and learning in mathematics and science. TIMSS is a project of the International Association for the Evaluation of Educational Achievement (IEA) and is directed by the TIMSS International Study Center at Boston College in collaboration with a worldwide network of organizations and representatives from the participating countries.
} 
Iceland, behind. In 2001, as PISA 2000 results were released, Portugal saw its students below average in all three areas (Literacy, Math, and Science) and much below the OECD average.

Results did not end the debate, as any politized debate is never resolved? But critics of the educational system gained more authority in demanding new reforms focused on the quality of education.

During the ensuing years, the debate continued and took many forms. Reforms in the school system were at times contradictory and served different purposes, but until 2015 they essentially went into one clear direction: to pay more attention to the results.

In the following sections, I will detail the history of these changes and highlight various reforms that facilitated a better performance of Portuguese students in largescale international surveys. In Sect. 8.2, I will describe the pragmatic reforms done during 2001-2010. In Sect. 8.3, I will explain in detail the reforms undertaken during the years 2011-2015, a period that saw a great improvement in students' results. In Sect. 8.4, I will highlight what modern twenty-first century concerns were put in place. In Sect. 8.5, I will conclude.

\subsection{From 2001 to 2010: Pragmatic Times Yield Pragmatic Reforms}

If we want to pinpoint a date for the triggering of the positive reforms that led to steady and significative improvements in the Portuguese system, we could point to 2001. It was then that the Minister of Education released - for the first time - the average results per school based on the high-school exit exams. This ended a bitter public debate. For years, opinion makers, journalists, and some politicians in the opposition to the ruling party ${ }^{5}$ had been claiming the right to know schools' results. For years, the ruling party blocked this disclosure. It was only through threats of legal action, based on the law of disclosure of administrative data, ${ }^{6}$ that the government was forced to release these data.

\footnotetext{
${ }^{4} \mathrm{PISA}$ is the Organization for Economic Co-operation and Development (OECD) Programmed for International Student Assessment. Every 3 years after 2000 it tests 15-year-old students from all over the world in reading, mathematics and science. The tests are designed to gauge how well the students master key subjects in order to be prepared for real-life situations in the adult world.

${ }^{5}$ Here as in other parts of this text, when possible I purposely avoid the naming of ministers and political parties, as I believe different people in different situations could act differently. The issues are political in nature, but independent of the parties. Fortunately, or unfortunately, stands in education are transversal to the left and the right, and to put labels may contribute to confuse the questions.

6 "Constituição da República Portuguesa", art. 268. 'and "Código do Procedimento Administrativo" approved by D-L 442/91, 15 of November, revised by D-L 6/96, 31 of January.
} 
When data were finally released, parents, school administrators, teachers, students, and the general public could look at each school and see how it stood in a comparative framework. Soon, the data release was taint with rankings made by different newspapers and entities and this diverted the attention from the essential problems. But the data release was an eye opener and let to positive effects in the country. People realized that there were very good schools and not so good schools in wealthy areas. Similarly, there were very good schools and not so good schools in disadvantaged areas.

Of course, there was and there is a positive correlation between the socioeconomic status (SES) of students and schools' results. But it also become clear that some schools are more effective than others at bridging the achievement gap related with SES. Each school could do better and that the economic conditions are not an unsurmountable obstacle. Schools can fight against the disadvantageous background of their students. Schools can do better.

By November 14 of 2001, the OECD released the first PISA results. ${ }^{7}$ This international survey started in 2000 in 28 OECD countries and four partner countries. Later, other 15 countries and regions joined the same 2000 survey. Portugal participated in PISA since its inception, as most European Union countries did.

Portuguese results were disappointing: performance was below the OECD average in all three areas (Reading, Mathematics, and Science). In Reading, only four countries had a lower average (Russia, Latvia, Mexico, and Brazil); in Mathematics, only four countries had a lower average (Greece, Luxemburg, Mexico, and Brazil); and in Sciences only three countries had a lower average (Luxembourg, Mexico, and Brazil).

These results prompted an outcry from many influential opinion makers and some politicians. When a new government took office a few months later, in April 2002, the new minister of education immediately announced a task force for improving the curriculum and the constitution of a commission for the improvement of mathematics and sciences teaching. Exams were established for Mathematics and Portuguese subjects at the end of compulsory schooling (then the 9th grade) ${ }^{8}$ The country was in an educational reform mood.

Then, things changed again. Prime minister Durão Barroso resigned to be appointed President of the European Commission. The President dismissed the government and new elections were held. The then main opposition party won the elections and a new government took office in March 2004. It's telling that the new education minister, although appointed by a rival party, maintained the exams instituted by the previous government. In fact, it was this new minister who for the first time presided over the new exams, held the same year in June.

The same minister decided to concentrate efforts on mathematics and reading. She instituted an action plan for mathematics ("Plano de Acção da Matemática")

\footnotetext{
${ }^{7}$ OECD/UNESCO Institute for Statistics (2003)

${ }^{8}$ The first time these exams were held was at the end of the school year 2004/2005. They are still in place.
} 
and supported another one for the Portuguese language ("Plano Nacional de Leitura"). The plan for revamping mathematics concentrated on elementary and middle school mathematics and was very controversial. It was largely made of actions for explaining to teachers how to teach mathematics according to the recommendations that had already been largely followed. It didn't address the shortcomings of math education as it had been practiced during the last decade: a poorly structured curriculum, the avoidance of basic skills training with the pretext of eschewing rote learning, the abuse of calculator's use since first grade, and the sort. Nevertheless, this plan helped concentrate efforts on the teaching and learning of this basic discipline and helped to focus on this discipline results in school and national tests.

The reading plan was noncontroversial. It was essentially noncurricular and only established voluntary actions, mainly in school and public libraries, to popularize reading amongst the youngsters. Although its effects have never been seriously evaluated, it also helped to focus attention on this basic subject.

The next minister stayed in office for less than 2 years (October 2009 to June 2011) and continued this line of efforts to pay attention to the results on basic subjects. She needs to be credited with the introduction in Portugal of the first learning standards, following an Anglo-Saxon lead. These standards did not replace the existing curriculum, they simply tried to introduce a clearer structure to it.

In Portugal and other countries with a very centralized systems, the curriculum is subject-based and essentially consists of a set of official documents called programs ("programas"), which detail the topics to be covered in each school discipline or subject.

These programs typically explain the choice of topics, the way to approach each topic, and the learning objectives. But they go further. They often explain the type of assignments and projects that should be given to students, the materials and the required readings. They may detail pedagogical recommendations, including teaching methods, assessments, and other means used to convey the course content. However, they are usually vague regarding intended learning outcomes.

In contrast to programs, standards typically organize the course contents sequentially, highlighting the learning goals, and the level of attainment desired for each content. They abstain from pedagogical recommendations and favor the setting of detailed learning outcomes.

The first learning standards appeared in 2010 and 2011. Although they represented a progress from the vague programs of the time, they still included pedagogical recommendations mixed up with learning outcomes, they still didn't clearly highlight knowledge goals, and they were still vague in some areas.

By December 2010, PISA 2009 results appeared and showed an important improvement in all PISA areas. Some analysts stressed the importance newly instituted 9th grade exams may have had, while others stressed the new policies of increased attention to results in basic subject areas. In my opinion, both points are correct. 
In June 2011, elections were held, a new majority was formed, and a new prime minister was chosen. I was then appointed as an independent minister responsible for Education (all levels) and Science.

To understand the political and economic background during these years, one must recall that in June 2011, Portugal was coming to grips with the most serious financial crisis of its recent history. The state was financially broke and unable to adopt the common short-term solutions for monetarily independent countries - as a member of the European community the country had adopted the common currency, the euro, 12 years earlier. In May 2011, a bailout was agreed with the IMF and the EC, and the government fell. Elections were held and a new prime minister, the social democrat Pedro Passos Coelho was appointed. The bailout agreed by the previous government included drastic spending cuts. Along with the health and social security systems, education expenditure had to be seriously reduced.

Against this background, and abiding by a Law approved by the previous parliament, we expanded compulsory education from 9 to 12 years and decided to enrich an outdated curriculum, which had no compulsory English, for instance.

When expanding compulsory schooling, we were very conscious of the fact that there were risks associated with this move. Firstly, there were logistic risks, as more students enrolled in secondary schools with limited capacity. These risks were dealt with a very detailed national and local planning and we were able of accommodate all students. Secondly, there were risks of quality decrease. We had still present the concerns on quality decrease in education, on the aftermath of 1986 extension of compulsory schooling from the 6th to the 9 th grade. This was actually the first large discussion on education in the ministers' council. To my pleasant surprise, some ministers made echo of the concern on quality and we introduced a completely new plan for improving the quality of education and get special help for students with academic difficulties. All this is discussed in detail at Sect. 8.3.

I am still amazed by the fact that even under budget cuts, salary cuts and increased responsibilities, teachers and schools were able to answer the call, expand schooling, accept more students, offer a more diverse curriculum, and still improve education.

\subsection{From 2011 to 2015: A Deliberate Effort to Strengthen the Curriculum and Attain Demanding Curricular Goals}

The reforms put in place during the school years 2011-2012 through 2014-2015 were clearly oriented towards quality learning. We can group these reforms in five essential areas. 


\subsubsection{A Demanding and Well-Structured Curriculum}

Everything starts with the curriculum, as we clearly stated and repeated throughout the education reform debates. ${ }^{9}$ The curriculum defines learning goals, and learning goals are the starting point for all education.

In Portugal, curriculum is defined centrally and approved by the minister. For instituting the new standards and programs, we set up groups of experts for each discipline. Typically, each of these groups was constituted of (i) expert teachers of the discipline, (ii) university-level professional researchers of the same discipline, (iii) cognitive psychologists and other researchers on the discipline education. This contrasted with previous discipline group designers, which were typically constituted of (i) teachers' associations members and (ii) professors from colleges of education.

\subsubsection{Knowledge Comes First}

Even when we stress skills, the so-called competencies, attitudes, or civic goals, the school loses its purpose if it doesn't convey knowledge. Even when we are keen on critical thinking, cooperative learning, and the application of knowledge, we shouldn't forget that knowledge is the base for civic participation, for critical thinking, for action.

We had it very clear: without a base in substantive knowledge, students cannot get an appreciation for any subject, cannot develop advanced skills, cannot progress in any career, cannot attain higher-level knowledge and skills in any subject.

When we overstress skills and competencies, we may lose knowledge grounding. and forget that skills are essentially domain-based. Generic skills are difficult to develop, and skills' transfer is limited. Without solid domain-specific knowledge, students do not get an appreciation for any discipline, do not realize the structure of any subject. Mathematics is not a collection of tricks, the same way writing is not a collection of rules and literature is not a collection of grammatically correct sentences.

This means that students need to get in-depth knowledge in some subjects. Breadth should not and cannot be attained at the expense of structured knowledge.

\subsubsection{To Prioritize Basic Knowledge}

An illiterate child is forever handicapped if he or she doesn't acquire fluency in reading. A mathematically deficient child is forever handicapped if he or she doesn't develop basic arithmetic ability, elementary graphical data analysis capability, and rudimentary formal logic skills.

\footnotetext{
${ }^{9}$ See, e.g., Crato (2018).
} 
As the Australian New South Wales Department of Education put it,

"We know that literacy and numeracy skills are the foundation for success in learning and in life." [and so, our] "efforts will ensure our students have the essential literacy and numeracy skills they need because those literacy and numeracy skills are described clearly, taught explicitly, assessed meaningfully and reported regularly in all NSW schools over the next four years." 10

The first decision we took in developing a more demanding and better structured curriculum was to define priorities. And the priority was the focus on fundamental subjects and basic knowledge. This means that we allotted more time for Mathematics and Reading right at the start of elementary schooling, and we organized better the curriculum for these basic subjects. Later, we extended this priority to other basic subjects, namely History, Geography, Sciences, and English.

As we reorganized the curriculum, we decided the opposite of a complete overhaul of the previous curricular documents: we decided to adopt small incremental changes, but all in the same direction. This way, instead of rewriting all the programs, we started organizing them by supplying new standards ("metas curriculares"). These new standards had multiple pedagogical purposes:

- To clarify the basic topics needed to be mastered by students

- To set up the desirable levels of attainment for each topic

- To be more demanding on each basic discipline content

- To organize topics in a better structured and clear progressive way

- To help scaffold knowledge and skills in levels or layers of domain

At the same time, these standards intended to be clear to everybody involved:

- Teachers would understand better what students should attain

- Parents would be able to help their children and check how they are advancing in the classroom

- Textbook authors would know better what is expected from them

- External textbook reviewers and certifiers would have more clear guidelines regarding the evaluation and certification of textbooks

- Exam and national assessment test designers would know better what to select for testing and the levels of attainment expected from students

This general alignment proved essential to get everybody on board, all aiming to attain the same goals. Although this seems obvious, it's worthwhile to underline it: a well-defined curriculum helps textbooks to be aligned with the desirable goals, helps teachers, helps the development of reliable and valid national assessments, helps parents, helps students.

\footnotetext{
${ }^{10}$ New South Wales Government Department of Education (2017). See also Centre for Education Statistics and Evaluation (2017).
} 


\subsubsection{Teaching Resources Aligned with the Curriculum: Textbook Quality}

Textbooks have been and still are a central tool for conveying the curriculum. Textbooks can be in paper, digital, or blended, but the most important thing is that they should be of high quality in order to help teachers and students.

Important steps were taken in 2006 for improving textbook quality. The parliament and the government approved new legislation ${ }^{11}$ for the evaluation and certification of textbooks by independent entities. This was a major step in improving the quality of textbooks.

As we redefined curriculum content and organization, the new standards helped this process by setting clear guidelines that textbook authors used. This was put in practice as soon as December 2012 and reorganized in $2014^{12}$ in view of setting up a general and systematic procedure for the analysis, correction, and certification of textbooks.

Textbooks aligned with standards and thus also aligned with standardized evaluation proved to be helpful to teachers, simplifying their work ${ }^{13}$ and providing a secure guide. This somehow replaced teachers' networks that in Portugal are less active and in some other countries have proved essential for aligning teaching standards across schools. By the same token, students and parents could use textbooks to attain the desired learning outcomes.

\subsubsection{Frequent and Reliable Assessment}

A lesson stressed in OECD studies is that assessment should be aligned with standards. ${ }^{14}$ We should apply this evidence, based on statistical analyses, to student evaluations. In Portugal and other southern European countries, including France, assessments serve multiple purposes ${ }^{15}$ :

\footnotetext{
${ }^{11}$ The evaluation and certification of textbooks by external independent certifying centers was set up in a 2006 Law (Lei n. ${ }^{\circ} 47 / 2006$ de 28 de Agosto), regulated by the government (Decreto-Lei n. ${ }^{\circ}$ 261/2007 de 17 de junho) and further defined in 2012 (Decreto-Lei n. ${ }^{\circ}$ 258-A/2012 de 5 de dezembro) and 2014 (Decreto-Lei n. ${ }^{\circ}$ 5/2014, de 14 de janeiro).

${ }^{12}$ Decreto-Lei n. ${ }^{\circ} 258$-A/2012, de 5 de dezembro, set up a procedure for quick adaptation of textbooks to the new standards and Decreto-Lei $n .{ }^{\circ} 5 / 2014$, de 14 de janeiro

${ }^{13}$ As the head of the major Singapore textbook publishing house put it with good textbooks, "teachers can concentrate on students' learning; so instead of preparing materials, they prepare good lesson plans". Joy Tan, communication at the Second Cambridge textbook Summit, at Reykjavik, June 2019.

${ }^{14}$ Idem, ibidem, p. 42 and passim.

${ }^{15}$ Morris 2011
} 
- National standardized high-stakes tests, in short, exams, that may determine the retention or continuation of studies; they are usually taken at the end of a school cycle (lower and upper elementary, middle, and high school)

- National standardized low-stakes tests that act as surveys of educational progress, with no impact over students, schools or teachers

- School-designed tests

- Class tests designed by individual teachers

At the outset of the democratic revolution of 1974, the successive governments abolished many of the national exams, and tried other types of tests. Only at the end of the twentieth century, a new socialist government set up a new state-run subdepartment in charge of organizing a more modern testing framework for the highschool exit tests. ${ }^{16}$ Later, the same government introduced low-stakes standardized tests, which first were just sample surveys and only later were applied to the whole school population in certain grades.

The system gave some information about students' achievement levels, but it was very limited. After a few years, low-stakes tests were largely discredited in the public opinion. One of the reasons for this was the fact that they had absolutely no influence on students, teachers, or schools. At the same time, many opinion makers and some scientific societies, namely the Portuguese Mathematical Society (SPM), criticized the fluctuation in the difficulty level of some exams. In fact, exam average results had fluctuations from year to year in the order of 50\%. This was the case in 2008 for Mathematics, which was difficult to explain by sudden changes in students' performance leaving room for the explanation that changes were due to poor test design and/or from tampering with the difficulty of the tests.

This situation prompted us to introduce a major reform. A 2013 law $^{17}$ created a $^{2}$ new assessment institute, the "Instituto de Avaliação Educativa, (IAVE)", with the mission of organizing all external students' evaluation, both low-stakes and highstakes standardized tests. This law stressed a well-known result from cognitive psychology, according to which evaluation reinforces retrieval in a way that helps knowledge reinterpretation and consolidation. ${ }^{18}$ This 2013 law may well be one of the rare ones in the world that directly cites results from modern cognitive psychology.

Two principles guided the creation of this institute. The first principle was the need to create evaluation instruments with greater validity and reliability, allowing to compare results from year to year. ${ }^{19}$ The preamble to the law also recognized that

\footnotetext{
${ }^{16}$ The "Decreto-Lei n. ${ }^{\circ} 229 / 97$, de 30 de agosto" created the "Gabinete de Avaliação Educacional (GAVE)"

17 "Decreto-Lei n. '102/2013 de 25 de julho".

${ }^{18}$ See, e.eg, Roediger and Karpicke (2006).

A general reference on retrieval and learning as well as other educational applications of cognitive psychology to education is McDaniel and Callender (2008).

19 “a aplicação de instrumentos de avaliação válidos e fiáveis, construídos de forma a permitir a comparação temporal e transversal dos resultados.” (D-L 102/2013).
} 
external evaluation with these characteristics plays an important regulatory role, both helping the validity of all other evaluation instruments and promoting equity through a fair assessment for different schools and regions across the country. ${ }^{20}$

The second principle was the need for and independent evaluation. The previous department (GAVE) was under the direct control of the minister and so the tests' difficulty could be tampered for political purposes. The new institute (IAVE) was directed by a General Council constituted by members appointed by different institutions, including public and private universities, the schools' principals' assembly, the private schools' association, teachers' associations, and scientific societies. Moreover, independence was enshrined into law, preventing ministers from directly instructing the institute. Exams' orders from the minister's cabinet had to be written and made public. ${ }^{21}$

\subsubsection{A Plan for School Dropout Reduction and Success Promotion}

To have a demanding curriculum and standardized student evaluation has been very controversial during the last decades. Some have argued that these two factors magnify social inequality and harm the children coming from disadvantageous backgrounds. ${ }^{22}$ We have argued the opposite: a serious education and reliable assessment according to national standards is the only way to help children from disadvantageous backgrounds to prepare for an active, productive, and independent life.

I think we have taken a moderate and effective approach. In parallel to striving for high academic standards, we devised a series of measures to improve students who trailed behind and, at the same time, to allow more advanced students to flourish by pursuing their specific interests. These measures were set out as early as 2012 in a special law $^{23}$ and complemented by regulatory legislation that made the support to students with academic difficulties compulsory:

\footnotetext{
20 "a avaliação externa desempenha um papel essencial, seja pelo facto de auxiliar uma avaliação fiável em vários momentos da escolaridade, incluindo a avaliação formativa e sumativa interna à escola, seja pela equidade que permite promover na valoração dos conhecimentos e capacidades desenvolvidos nas diversas escolas e locais do país"

${ }^{21}$ Although I'm still proud of this reform, I regret the institute independence did not go as far as it should. Unfortunately, the institutions that appointed the General Council acted perfunctorily, they did not follow the institute activities. Maybe a different type of legal design for this council could have helped it to gain more independence.

${ }^{22} \mathrm{As}$ we know, this is an old debate, recently fueled by a standards and testing policy designed during the George W. Bush administration and pursued in many aspects by the Barak Obama administration. Critics go from rightly pointing the limitations of standardized testing (NCTE 2014) to radically associate curriculum and testing with eugenics and purposed exacerbation of inequalities (see, e.g., Wayne 2009).

23 "Decreto-Lei 176/2012 de 2 de agosto."
} 
- For elementary schooling (1st-6th grades), student-study help and special extra help at scheduled times

- Temporary grouping of students with difficulties for special extra help, while maintaining them in their original class

- Incentives to schools for using teachers' school hours for helping teachers and students in different grades (see comment below)

The first measure essentially led to teachers using their free or idle school time for useful purposes. The second measure could be called "temporary tracking", but in reality it's the opposite of tracking, it's a school effort to maintain classes intact. The third measure was very successful, as elementary teachers used help from middle- and high-school teachers to teach and to help teach subjects such as mathematics, reading, music, and physical education at arranged times.

\subsubsection{School Incentives and School Autonomy}

With a very limited budget and under pressure from the IMF and the EC to further reduce spending, incentives had also to be very limited. This may well have been a blessing, as incentives were mainly tied to school improvements and not with monetary rewards tried elsewhere and that proved to be very limited and highly controversial. ${ }^{24}$

In addition to moral incentives, such as prizes and public recognition from published school results, incentives were limited to the increase of teacher hour credits.

In order to understand the system, we must know how the highly centralized Portuguese school system works. Each school year is prepared with a tally of students enrolled and an estimate of the number and characteristics of teachers needed. Those needs that aren't covered from existing teachers in the school staff are supplied centrally by the ministry by using idle teachers from nearby schools or by temporary hiring of new teachers. After this process is over, the ministry supplies some extra teachers for supplementary needs. These supplements are counted as "teachers credit hours". Every school likes these credit hours as they allow for alleviating the contact hours of staff teachers and for organizing extra-curricular activities. Up to 2012, this worked in an automatic fashion. After 2012, we developed a complex system to increase credit hours to schools as that proved to be able to improve students results with these extra resources.

\subsubsection{Incentives to Schools Tied to Students' Improvement}

This system took into consideration students internal and external evaluations, retention and dropout rates. Schools got credits for:

${ }^{24}$ See, e.g., Shifrer et al. (2017) and the references therein 
- raising their internally evaluated student results

- raising their externally evaluated student results

- obtaining good externally evaluated student results

- reducing the retention and dropout rates

and these credits were penalized for:

- having internal evaluations higher than standardized external evaluations.

In addition, these credit computations took into consideration the recent past in school performance and could be adjusted if the student background changed.

The main criticism to this system is that it rewarded schools that could improve and penalized those that didn't improve. But I think this "criticism" results into a favorable appreciation of the system. Resources should be employed for the benefit of students.

\subsubsection{School Autonomy}

This incentives' system could only work thanks to some increase in school autonomy. ${ }^{25}$ The moto was the opposite of what some previous governments had sustained: we wanted freedom in the processes but external evaluation of students; previous governments wanted to dictate pedagogic practices and to avoid evaluation. Thus, they controlled processes instead of measuring outcomes.

This increased school autonomy allowed schools to organize teacher hours freely, to switch teachers and schedules, and to organize subjects according to a year or cycle logic. Most importantly, it allowed schools to freely use their resources in order to put in place the promotion-of-success measures described in Sect. 8.3.3. For many observers, such as north American ones, this is trivial, but for a highly centralized system such as ours this was a significant change.

\subsubsection{Parallel Offers and Vocational Tracks}

Another major reform was the slow change in the vocational system. Vocational tracks were abolished after the democratic revolution, but slowly restored with the creation of technical tracks in 1983 and the creation of secondary professional schools in 1989. However, the vocational system was very unequal and not always completely aimed at providing students with the training necessary for a modern

\footnotetext{
${ }^{25}$ It's one of my greatest frustrations the fact that we were unable to significantly increase school autonomy. In fact, we learned the hard way that very few agents in our society want greater autonomy for schools. Many parents' associations want the State to take care of all charges and responsibilities, many principals avoid hard decisions, and, above all, unions oppose fiercely anything that departs from national collectively negotiated agreements.
} 
profession. For many private schools, it was a business completely dependent on public subsidies. For many semi-private schools owned by municipalities, it played a political role in employing teachers and technical staff. In many cases, the focus wasn't on students training: offered courses depended more on local resources than on youngsters' needs or job market needs.

Reforms started in 2012 had to take into consideration the fact that compulsory schooling was extended from 9th to 12th grade, which means that vocational highschool tracks could and should become part of the compulsory schooling. Our reforms went essentially into these directions:

- To divide vocational tracks into two streams: one directed at regular students opting for a less academic training that could prepare them for entering a technical profession, another directed at students with difficulties who needed, temporarily or for the remaining schooling, more practical and hands-on activities. Without this division, vocational studies would always be associated with the idea of a second choice. ${ }^{26}$

- To associate industry to the vocational training. This involvement was from the start and integrated at all levels of training: in the creation of specific programs and courses, in lab trainings, and in the final stage of vocational training.

Although businesses were not paid for their contribution to the students' training, they gladly joined the programs. Here, we not only witnessed a generous contribution to the future of the country but also a defense of business interests: as they were contributing to the job market needs, they were preparing human capital for their counterparts. This was also a surprising trend. Registering a serious vocational investment, businesses contributed with human resources such as training personnel and with material resources such as access to factory tools and machinery, free transportation and free meals to students. In the first year of this program, about five thousand firms of all sizes contributed to the program. In the second year, about twelve thousand.

\subsection{A Curriculum for the Twenty-First Century}

There are many ways in which our reforms were oriented towards twenty-first century needs. The first, although apparently redundant, and only apparently so, deserves to be stressed: the focus on quality.

\footnotetext{
${ }^{26}$ The same division, or even into more than two tracks, exists in countries with a more developed vocational system such as Germany, Switzerland, and Austria. Unfortunately, in 2016 and for ideological reasons, this division was abolished. Students in the remedial track returned to previous nonorganized ad hoc modular training with no compulsory academic courses (the so-called CEF and others).
} 


\subsubsection{Providing High-Quality Education for All}

The situation around the world has improved tremendously, but in education we still have inexcusable gaps. A recent UNESCO report is correctly titled "More Than One-Half of Children and Adolescents Are Not Learning Worldwide". ${ }^{27}$ As described in this report, the fraction of children and adolescents not achieving minimum proficiency levels (MPL) for their age group is 56\% for mathematics and 58\% for reading. This phenomenon is not exclusive of low-income countries. The same numbers for North America and Europe are, according to the same source, 14\% for both areas.

For Europeans, it is even more worrisome to know that these numbers are not improving. The European Union had set a 2020 target of reducing the share of low achievers in PISA $^{28}$ to $15 \%$, but the average for all member states is not approaching this target.

For mathematics, the share of low achievers in 2015 was $22.2 \%$ in 2015, up slightly from $22.1 \%$ in 2012 . For reading, the corresponding shares were $19.7 \%$ in 2015, up from $17.8 \%$ in 2012. And in Science, the corresponding shares were $20.6 \%$ in 2015 , up from $16.6 \%$ in 2012 .

As the EU Commission sadly recognizes, only two countries were able to reduce the share of low achievers simultaneously in all three PISA domains: these countries were Sweden and Portugal. ${ }^{29}$

\subsubsection{To Promote Equal Opportunities Through a Demanding Education}

I think all previously quoted numbers make it very clear: to have a high-quality education for all children and young adults is not an outdated goal, even in Europe. And we cannot approach it unless we pay special attention to the quality of education for all, including the less favored by their academic environment.

It is telling that the country improved in almost all common indicators. Dropout rates decreased sharply. In 2000, early leavers were at a rate of 43.6\%. In 2010 this rate decrease to $28.3 \%$ and in 2015 , it attained $13.7 \%$, thus decreasing $14.6 \%$ in 5 years, a rate of almost 3\% points per year. Remarkably, after 2012 this decrease happened in parallel with a decrease in 25-year-old and younger unemployment. ${ }^{30}$

It is also telling that Portugal was able to increase the academic levels of those at the bottom of the scale at the same time the country was fighting for a demanding and well-structured education. As the OECD report on PISA 2015 points out:

\footnotetext{
${ }^{27}$ UNESCO (2017).

${ }^{28}$ Those with the very minimal proficiency levels 1 and 2 in the PISA scale.

${ }^{29}$ European Commission (2016).

${ }^{30}$ Pordata, consulted 3 August 2019.
} 
"Macao (China) and Portugal were able to 'move everyone up' in science, mathematics and reading performance over the past decade by increasing the number of top performers while simultaneously reducing the number of students who do not achieve the baseline level of skills. Their experiences demonstrate that education systems can nurture top performers and assist struggling students simultaneously." The section of the report where this was written is significantly titled "Countries do not have to choose between nurturing excellence in education and reducing underperformance". ${ }^{31}$

I will add that the way to improve education for those from a disadvantaged background is precisely through a demanding, well structured, and ambitious education. As we said at the time, "A exigência é a arma dos pobres", idea that I can roughly translate as "A challenging education is the only instrument for poor people to progress".

\subsubsection{To Focus on Permanent and Central Education Pillars}

Larry Sanger, co-founder of the Wikipedia is certainly a creative person, an innovator, and someone who has been ahead of most of us. Talking about education he reflected on what type of knowledge was essential for the twenty-first century:

"The specific skills for the work world were, and largely still are, learned on the job. So let's see, which would have been better for me to learn back in 1985, when I was 17: all the ins and outs of WordPerfect and BASIC, or U.S. History? There should be no question at all: what I learned about history will remain more or less the same, subject to a few corrections; skills in WordPerfect and BASIC are no longer needed." ${ }^{32}$

As we are leaving in a rapidly changing word, jobs, professions, and necessary skills are evolving at a great speed. In order to prepare young people for the future, it's more than ever necessary to focus on a basic education that allows young people to adapt in this changing word. This means that the permanent basic pillars of an active and productive civil life need to be acquired by all youngsters:

- Reading and writing fluently helps to understand and organize ideas, a wide vocabulary helps understanding and expressing complex sentiments, impressions, instructions and ideas.

- Mathematics, statistics and logic are crucial to quantitatively reason about our word, to understand society, jobs, finance, the environment, and our society.

- History and geography solid and wide knowledge help understanding the word and be critical about it.

\footnotetext{
${ }^{31}$ OECD (2016). Italics in the citation are mine.

${ }^{32}$ Larry Sanger (2011).
} 
- Sciences are everyday more necessary to critically develop an understanding of machines, computers, medicine, the human body behavior, the environment and the society.

All these areas are basic and essential for the future. We don't need to invent much. If we provide young people with a solid knowledge and vast skills on these areas, we are already preparing them well for further studying, further learning, and further productive activities.

Of course, we need much much more. As an example, I'm listing two additional areas:

- Art, in its various forms, from music to painting to theatre make us better human beings

- Literature and languages help people widening their horizons and enlarging their professional ambitions and possibilities.

But the main point is simple: while we are failing on the basic pillars we are failing on young people's future.

\subsubsection{To Adapt Vocational Training to Country's Future Needs}

We already encountered this topic in Sect. 8.3.5. as a recap, I will only stress that a vocational training established by the cooperation of schools and firms facilitates its orientation for the country needs and so may offer a productive future for students involved.

\subsubsection{To Increase Curricular Flexibility and Modernity a Par with a Focus on Central Subjects}

Curricular flexibility and a modern approach to education are not in opposition, rather in complementarity with a focus on the basic pillars. Our approach to curricular flexibility ${ }^{33}$ is to increase schools' power in deciding how to run and how to complement the national curriculum.

This approach allows the modernization of teaching in various crucial aspects:

- look at problems from different angles and

- advance varied examples

- extract general principles from examples and problems

\footnotetext{
${ }^{33}$ The legal instrument "Portaria n. ${ }^{\circ} 44 / 2014$ de 20 de fevereiro" established a flexible administration of the curriculum by the schools, allowing them to freely use $25 \%$ of the curricular time, but required that the basic subjects should abide by the curricular goals.
} 
- propose challenging tasks and problems

- practice cooperation of different subject approaches

However, all this should be embedded in the general class activities to convey knowledge and develop skills. There is no point in promoting transfer, or deep thinking, or creativity outside of substantive learning.

\title{
8.4.6 To Increase Self-Regulation of the Educational System Through External Evaluation
}

\begin{abstract}
Almost everybody now agrees that modern education cannot continue to be a highly centralized and rigid activity, as it still is in many countries. At the same time, almost everybody agreed that a nation should take upon its shoulders the task of providing good education to all youngsters.

International examples of failure to achieve reasonable education levels with school autonomy and to have standardized assessment serving education progress show how difficult these trends are difficult to conciliate. Our lesson is clear: external evaluation helps the educational system to progress and regulate itself without intrusive micromanagement form the state authorities.
\end{abstract}

\subsubsection{To Provide Incentives to Apply Modern Science Consensus}

There are many misunderstandings about how we learn, and cognitive psychology can help us correcting these misunderstandings and guide us to adopt basic wellestablished principles.

An old and still key finding in cognitive psychology is the fact that we learn by integrating new knowledge in already acquired knowledge. The more we know, the more we can learn. I extract two conclusions from this finding. The first is that knowledge is important and the richer it is, the better we learn. The second is that by layering and organizing knowledge, a well-structured curriculum allows students to progress faster and in a more solid way than they can with a disperse set of activities or with a loose curriculum.

As a group of experts convened by the US National Research Council put it, "Learning with understanding is facilitated when new and existing knowledge is structured around the major concepts and principles of the discipline." 34

${ }^{34}$ National Research Council (2002). 
Another key modern finding in educational psychology is the fundamental role of assessment for memory retrieval and consolidation. ${ }^{35}$ Simple repetition, simple repetitive study, and disperse activities are much less useful than retrieving and reorganizing knowledge. Standardized national testing helps local formative assessment and so the reinforcement of knowledge and the practice of skills in various contexts.

Another key finding in cognitive psychology is the usefulness of interleaving the study of different subjects and of reencountering the same topics on different contexts. ${ }^{36}$ This is a powerful argument for relating subjects in a well-organized curriculum and for extensively using previous knowledge and skills for studying different subjects. Reinterpreting and explaining, both verbally and in writing, improves student's knowledge. The same applies for quantitative, data-analysis, and logic skills: by using these skills in different contexts we simultaneously reinforce these skills and the substantive knowledge students are acquiring.

\subsubsection{Preparing Teachers, Preparing the Future}

In education studies there are few consensuses, but there is certainly one regarding the importance of teachers for the quality of the education. ${ }^{37}$ Many studies and review studies have shown and highlighted the impact of teachers initial training on students short- and long-term educational success. ${ }^{38}$

In Portugal, teachers are experienced professionals, but this can change soon, as a large number of teachers is approaching retirement age. The latest published results show that at the elementary level (grades 1-4) there are 7.6 teachers who are 50 years of age or older for each teacher 35 years of age or younger. For middle and high school teachers (grades 5-12), the proportion is even more alarming: 14.6 to 1.

Contrary to some of the hype, the profession is still desired by young graduates: each time teaching positions are available, there are more candidates than places to fulfil. This sets the stage for strengthening the future of Portuguese education: to prepare, qualify, and select the best professionals.

We took three measures to improve initial teacher training.

- Regulating access to teachers' colleges and education programs at universities.

- When we took office, almost anyone with a high-school diploma could enter a teacher training program. Students could have failed their math courses; in all or in some grades during their 12 years of schooling, that they could still enter these

\footnotetext{
${ }^{35}$ Roediger et al. (2011) provide a summary of the host of potential benefits of practicing retrieving as a learning technique.

${ }^{36}$ See, e.g., Taylor and Rohrer (2010).

${ }^{37}$ See a comprehensive review in Hanushek and Rivkin (2006).

${ }^{38}$ See, e.g., Lee (2018), Hanushek et al. (2019) and the references therein.
} 
college-level programs. At this later level, they could take only some basic math in teacher preparation classes. At the end, they would be qualified to teach elementary school (grades 1-4) and upper elementary (grades 5 and 6), where they would need to teach basic arithmetic, geometry and data analysis.

- We changed this by instituting the need to pass an elementary math test at the end of high school in order to enter a teacher's college. ${ }^{39}$

- Surprising, there was no reaction from students or the from civil society to this measure. Only some teachers' colleges and some teachers' associations opposed this requirement as they feared their enrollment would drop.

- Extending requirements and adding subject content matter in teacher preparation programs.

- Typically, students who want to become teachers, enroll in a preparatory first cycle of 3 years (roughly equivalent to an undergraduate program in the US) and graduate with a university degree in education. In order to fulfill teacher licensing requirements, students must continue their studies and obtain a master's that focuses on subject content and teaching methods and pedagogy. Master programs include courses in two areas: (i) general education, i.e., philosophy or sociology of education, history of education, psychology, pedagogy and didactics, (ii) subject matter content, i.e., sciences, mathematics, grammar, literature, and so on, according to the specialization they want to acquire.

- We introduced two directives: (1) increased the number of credits required in teaching programs, resulting in master's degrees of four semesters, rather than three, and (2) increased the number of credits in the subject-matter areas. ${ }^{40}$ This way, teachers of English would have more English courses, teachers of Geography would have more Geography courses and so on.

- These measures went against a trend of increasing non-subject matter courses and decreasing the subject-matter required knowledge. Moreover, they addressed a shortcoming identified in data from exams of teacher candidates. These revealed a deficient preparation in subject matter knowledge.

- To introduce an entrance exam for teacher candidates.

- In the Portuguese system, teacher candidates applying to public schools are selected and placed at the national level by the national administration. Initial selection is based on graduation scores only. This provides the wrong incentives to teacher training schools, as they want to increase their enrollment and so they have pressure to increase students' graduation grades. This also provides the wrong incentives to students entering a teacher training program, since they must consider how to obtain the best grades upon graduation in order to get a teaching position.

\footnotetext{
${ }^{39}$ Portaria n. ${ }^{\circ}$ 91/2014 de 23 de abril.

${ }^{40}$ Decreto-Lei n. ${ }^{\circ}$ 92/2014 de 14 de maio.
} 
- We then followed the lead of many countries and introduced a national screening exam for all prospective teachers without tenure and for all teachers with a temporary contract with less than 5 years teaching experience (akin to substitute teachers). The results of the exams were appalling, ${ }^{41}$ as a high fraction of candidates could not answer basic reading, writing, and logic questions, neither they could they answer basic questions regarding the subject-areas they were trained to teach. Unfortunately, this measure was under great pressure to be abolished by some unions and some parties and was eventually abolished during the next legislative cycle. I still consider it a very important measure. Either it needs to be replaced by equivalent measures for selecting prospective teachers or it should be reinstituted.

\subsection{Conclusion}

As the twenty-first century began, educational news was not favorable to Portugal. International comparisons showed students lagging on major subjects. By 2015, the situation had changed, and many regarded Portugal as an example to follow. When we look back and see the major reforms done during these years, we recognize a movement towards attention to the results in basic subjects and towards better structuring the curriculum. During the period 2011-2015, which was analyzed in some detail here, this movement was reinforced. A major conclusion from the analysis of this period is that striving for the quality needed in the twenty-first century is a way to help progressing all students, especially those from disadvantaged backgrounds.

\section{References}

Centre for Education Statistics and Evaluation. (2017). How schools can improve literacy and numeracy performance and why it (still) matters. New South Wales Department of Education. https://www.cese.nsw.gov.au. Accessed 2 Oct 2019.

Crato, N. (2006). O 'Eduquês' em Discurso Directo: Uma Crítica da Pedagogia Romântica e Construtivista. Lisbon: Gradiva.

Crato, N. (2018). Everything starts with the curriculum. ResearchED 3. https://researched.org.uk/ everything-starts-with-the-curriculum/. Accessed 20 Nov 2019.

\footnotetext{
${ }^{41}$ Numbers do not represent existing teachers training, but they are extremely worrisome regarding the knowledge of prospective teachers. On the general test of reading, writing, basic knowledge and logic, $34,1 \%$ of the candidates failed. On the subject matter exam, a large fraction of teacher's candidates that passed the general exam also failed. For high-school candidates failure rates were 42.3\% for Biology and Geology, 63.2\% for Physics and Chemistry, 60.4\% for Portuguese. For elementary-school candidates failure rates attained $41.6 \%$ for Mathematics. Other areas, such as pre-schooling (1.3\%) and Geography (2.0\%) had much lower failure rates (Ministério de Educação e Ciência 2015).
} 
Donnelly, K., Nagarajan, A., \& Lipstein, R. L. (2019). Beyond the mirage: How pragmatic stewardship could transform learning outcomes in international education systems. http://seeingbeyondthemirage.com. Accessed 24 July 2019.

European Commission. (2016). PISA 2015: EU performance and initial conclusions regarding education policies in Europe.

Hanushek, E. A., \& Rivkin, S. G. (2006). Teacher quality. In Handbook of the economics of education (Vol. 2, pp. 1052-1078). Amsterdam: North Holland.

Hanushek, E. A., Piopiunik, M., \& Wiederhold, S. (2019). Do smarter teachers make smarter students?: International evidence on teacher cognitive skills and student performance. Education Next, 2019(Spring), 57-64.

Lee, S. W. (2018). Pulling back the curtain: Revealing the cumulative importance of highperforming, highly qualified teachers on Students' educational outcome. Educational Evaluation and Policy Analysis, 40-3, 359-381.

McDaniel, M. A., \& Callender, A. A. (2008). Cognition, memory, and education. In H. L. Roediger (Ed.), Cognitive psychology of memory, vol. 2 of learning and memory: A comprehensive reference (pp. 819-844). Oxford: Elsevier.

Ministério de educação e Ciência. (2015). Relatório de Aplicação da Prova de Avaliação de Conhecimentos e Capacidades no ano escolar 2014-2015.

Morris, A. (2011). Student standardized testing: Current practices in OECD countries and a literature review (OECD Working paper series no. 65).

National Research Council. (2002). Learning and understanding: Improving advanced study of Mathematics and Science in U.S. High Schools. Washington, DC: The National Academies Press. https://doi.org/10.17226/10129. Assessed 3 Oct 2019.

NCTE, National Council of Teachers of English. (2014). How standardized tests shape-and limitstudent learning, A policy research brief.

New South Wales Government Department of Education. (2017). Education literacy and numeracy strategy 2017-2020. https://education.nsw.gov.au. Assessed 20 Nov 2019.

OECD. (2016). PISA 2015 results (Volume I): Excellence and equity in education (p. 266). Paris: OECD Publishing. https://doi.org/10.1787/9789264266490-en. Accessed 10 Oct 2019.

OECD/UNESCO Institute for Statistics. (2003). Literacy skills for the world of tomorrow: Further results from PISA 2000. Paris: PISA/OECD Publishing, https://doi. org/10.1787/9789264102873-en. Assessed 20 Nov 2019.

Roediger, H. L., \& Karpicke, J. D. (2006). Test-enhanced learning: Taking memory tests improves long-term retention. Psychological Science, 17, 249-255.

Roediger, H. L., Smith, M. A., \& Putnam, A. L. (2011). Ten benefits of testing and their applications to educational practice. In B. H. Ross (Ed.), Psychology of learning and motivation. San Diego: Elsevier Academic Press.

Sanger, L. (2011). An example of educational anti-intellectualism, post of December 13, 2011. https://larrysanger.org/2011/12/an-example-of-educational-anti-intellectualism/. Accessed 3 Aug 2019.

Shifrer, D., Turley, R. L., \& Heard, H. (2017). Do Teacher financial awards improve teacher retention and student achievement in an urban disadvantaged school district? American Educational Research Journal 54(6), 1117-1153. https://doi.org/10.3102/0002831217716540. Accessed 20 Nov 2019.

Taylor, K., \& Rohrer, D. (2010). The effects of interleaved practice. Applied Cognitive Psychology, $24,837-848$.

UNESCO. (2017). Fact sheet no. 46.

Wayne, A. (2009). Unequal by design: High-stakes testing and the standardization of inequality. New York: Routledge. 
Open Access This chapter is licensed under the terms of the Creative Commons Attribution 4.0 International License (http://creativecommons.org/licenses/by/4.0/), which permits use, sharing, adaptation, distribution and reproduction in any medium or format, as long as you give appropriate credit to the original author(s) and the source, provide a link to the Creative Commons licence and indicate if changes were made.

The images or other third party material in this chapter are included in the chapter's Creative Commons licence, unless indicated otherwise in a credit line to the material. If material is not included in the chapter's Creative Commons licence and your intended use is not permitted by statutory regulation or exceeds the permitted use, you will need to obtain permission directly from the copyright holder. 